\title{
PENGARUH PENCEMARAN DEBU SEMEN PADA STRUKTUR DAN FUNGSI DAUN BEBERAPA JENIS TANAMAN BERDAUN LEBAR
}

\author{
Ahmad Taufiq $^{1)}$, Sasmita $^{2)}$, Alponsin ${ }^{3)}$, Zuhri Syam ${ }^{4)}$ \\ ${ }^{1,2), 3), 4)}$ Program Studi Biologi, Universitas Andalas \\ email $^{(1), 3)}$ :ahmadtaufiq@sci.unand.ac.id \\ email $^{4)}$ : zuhrisyambioua@gmail.com
}

\begin{abstract}
ABSTRAK: Fitur stomata daun beberapa spesies dari berbagai bentuk tumbuh tumbuhan yang berada di sekitar pabrik semen dipelajari dengan tujuan mengetahui ada tidaknya modifikasi anatomi daun yang meningkatkan toleransi dan kelangsungan hidup pada kawasan dengan polusi debu semen. Selain itu, kandungan klorofil dalam daun juga telah diperiksa. Sebagai perbandingan, studi yang sama juga telah dilakukan untuk komposisi spesies yang sama di lokasi yang tidak terpengaruh. Tiga bentuk habit tanaman yang berbeda diobservasi di dua lokasi tersebut: pohon, diwakili oleh Polyalthia longifolia, Acacia auriculiformis, Persea americana, dan Mangifera indica; semak oleh Syzygium myrtifolium, dan Ixora javanica; dan terna oleh Rhoe dan Aglaonema. Kepadatan stomata rata-rata di daerah yang terkena dampak adalah $173,16 / \mathrm{mm} 2$, sementara itu bisa mencapai 244,96 / mm2 di lokasi kontrol. Tren yang sama juga ditunjukkan oleh kandungan klorofil. Independent T-test mengungkapkan perbedaan yang signifikan ( $\mathrm{p}$-value $=0,037)$. Adaptasi dalam hal memiliki kandungan klorofil dari ketiga bentuk tumbuh di dua area yang berbeda juga tersedia dalam diskusi ini. Terna memiliki perbedaan terbesar antara lokasi $(0,33 \mu \mathrm{g} / \mathrm{mL})$, diikuti oleh semak $(0,31 \mu \mathrm{g} / \mathrm{mL})$ dan kemudian pohon $(0,2 \mu \mathrm{g} / \mathrm{mL})$. Uji ANOVA dua arah menunjukkan bahwa baik dalam hal bentuk tumbuh maupun lokasi, secara signifikan memengaruhi kandungan klorofil ( $\mathrm{p}$-value $=0,00$ ). Namun, tidak ada interaksi antara lokasi dan bentuk tumbuh dalam mempengaruhi kandungan klorofil (nilai $\mathrm{p}=0,652$ ). Kesimpulannya, dalam ketiga bentuk tumbuh tumbuhan, baik kepadatan stomata atau konten klorofil berkurang dengan polusi.
\end{abstract}

Kata kunci: Adaptasi; polusi; semen; stomata; klorofil

\begin{abstract}
The stomatal features of the leaves of several species of various life forms that grow around the cement factory are investigated with the aim of examining the anatomical modifications of the leaves which increase their tolerance and survival in the presence of cement dust pollution. In addition, the chlorophyll content in the leaves has also been examined. In comparison, the same study has also been carried out for the composition of the same species in unaffected locations. Three different life forms of the plant were investigated over two sites: trees, represented by Polyalthia longifolia, Acacia auriculiformis, Persea americana, and Mangifera indica; shrubs by Syzygium myrtifolium, and Ixora javanica; and herbs by Rhoe and Aglaonema. The average stomata density in the affected area was $173.16 / \mathrm{mm} 2$, while it could reach $244.96 / \mathrm{mm} 2$ at the control site. The same trend was also shown by the chlorophyll content. The Independent T-test revealed a significant difference ( $\mathrm{p}$-value $=0.037)$. Adaptability in terms of having chlorophyll content from all three life forms at different sites was also available in this discussion. Herbs has the greatest difference between sites $(0.33 \mu \mathrm{g} / \mathrm{mL})$, followed by shrubs $(0.31 \mu \mathrm{g} / \mathrm{mL})$ and then
\end{abstract}

Bio-Lectura: Jurnal Pendidikan Biologi, Vol 8, No 1, April 2021 
trees $(0.2 \mu \mathrm{g} / \mathrm{mL})$. The Two way ANOVA test showed that both life forms and sites significantly influenced the content of chlorophyll $(\mathrm{p}$-value $=0.00)$. However, there was no interaction between sites and life forms in influencing chlorophyll content ( $\mathrm{p}$ value $=0.652$ ). In conclusion, In all three life forms, either stomatal density or chlorophyll content decreases with pollution.

\section{Keywords: Adaptation; pollution; cement; stomatal; chlorophyll}

\section{PENDAHULUAN}

Masalah pencemaran lingkungan terutama di daerah perkotaan adalah pencemaran udara. Sumber pencemaran udara umumnya berasal dari kendaraan bermotor, industri dan rumah tangga. Peningkatan kendaraan bermotor dan sektor industri akan meningkatkan komposisi dan konsentrasi gas-gas dan partikel pencemar pada tanaman penghijauan kota. Jika faktor lingkungan mendukung, maka komposisi dan konsentrasi zat pencemar yang terserap oleh tanaman akan mempengaruhi tanaman dari tingkat peoses-proses biokimia, sel, jaringan, individu dan komunitas. Tanaman koleksi yang ditanam ataupun tumbuhan liar di sekitar kawasan pabrik PT. Semen Padang memiliki potensi besar terkontaminasi zat pencemar dari buangan residu semen pada cerobong pabrik dan juga dari emisi mesin serta kendaraan operasional di sekitar pabrik.

Pencemaran adalah masuk atau dimasukkannya mahluk hidup, zat, energi dan/ atau komponen lain ke dalam air atau udara. Pencemaran juga bisa berarti berubahnya tatanan (komposisi) air atau udara oleh kegiatan manusia dan proses alam, sehingga kualitas air/ udara menjadi kurang atau tidak dapat berfungsi lagi sesuai dengan peruntukkannya (Salami, 2018). Definisi ini sesuai dengan pengertian pencemaran pada (Undang-undang Pokok Pengelolaan Lingkungan Hidup No. 4 Tahun 1982).
Untuk mencegah terjadinya pencemaran terhadap lingkungan oleh berbagai aktivitas industri dan aktivitas manusia, maka diperlukan pengendalian terhadap pencemaran lingkungan dengan menetapkan baku mutu lingkungan.

Menurut Fardiaz (1992), yang dimaksud dengan pencemaran udara (air pollution) adalah bertambahnya bahan atau substrat fisik atau kimia tertentu ke dalam lingkungan udara normal yang mencapai sejumlah tertentu, sehingga dapat dideteksi oleh manusia (dapat diukur atau dihitung) serta dapat memberikan efek pada manusia, binatang, vegetasi dan material.

Pencemaran udara atau sering kita dengar dengan istilah polusi udara menurut Akhmad (2000) diartikan sebagai adanya bahan-bahan atau zatzat asing di dalam udara yang menyebabkan perubahan susunan atau komposisi udara dari keadaan normalnya. Pencemaran udara disebabkan oleh berbagai macam zat kimia, baik berdampak langsung maupun tidak langsung yang semakin lama akan semakin mengganggu kehidupan manusia, hewan dan tumbuhan.

Keadaan tersebut dapat menyebabkan kerusakan makrokopis dan mikrokopis daun, terakumulasinya logam pada jaringan tumbuhan khususnya daun, serta akan menyebabkan pengguguran daun. Daun adalah dapur pembuat makanan tumbuhtumbuhan. Daun inilah yang 
merupakan pabrik fotosintesa. Permukaan atas daun tertutup oleh selapis sel tunggal yaitu epidermis atas. Sel-sel ini sedikit atau tidak memiliki kloroplas. Sel-sel tersebut juga mengeluarkan suatu zat transparan seperti lilin yang dinamakan kutin. Bahan ini berbentuk kutikula, yang berfungsi untuk mengurangi hilangnya air dari permukaan (Treshow dan Anderson, 1989). Di bawah sel-sel epidermis atas tersusun satu atau lebih barisan sel yang membentuk lapisan pagar/lapisan palisade. Di bawah lapisan palisade terdapat lapisan bunga karang. Terakhir, dibawah lapisan bunga karang terdapat lapisan palisade bawah dan jaringan epidermis bawah yang menyerupai lapisan epidermis atas (Fitter dan Hay, 1994).

Seberapa besar pengaruh zat pencemar akibat kegiatan pabrik dan transportasi terhadap tumbuhan di sekitar kawasan salah satu pabrik Semen di Kota Padang belum diketahui dengan pasti, sehingga diperlukan studi ini. Disamping itu pengungkapan informasi tentang potensi kerusakan yang ditimbulkan oleh kegiatan pabrik Semen ini penting dan perlu dilakukan sebelum benarbenar menimbulkan dampak yang lebih lanjut terhadap lingkungan.

\section{METODE PENELITIAN}

Penelitian dilakukan di lahan terbuka hijau di sekitar kawasan pabrik PT. Semen Padang dan di beberapa tempat di luar kawasan yang terkena dampak kegiatan pabrik. Metode yang digunakan adalah survey langsung ke lapangan. Tingkatan tumbuhan yang diambil untuk dianalisis dibedakan menjadi tiga kelompok berdasarkan stratifikasi atau habitnya, yaitu pohon, semak dan terna. Hal ini dilakukan guna melihat perbedaan dampak yang ditimbulkan oleh polutan sesuai dengan peluang ketercemaran tumbuhan tersebut berdasarkan bentuk tumbuhnya. Adapun sampel daun yang dikoleksi adalah yang tidak terlalu tua dan daun yang tidak terlalu muda. Letak daun pada pohon diambil dari arah timur dan barat, masing-masing pada tajuk bawah, tengah dan atas (Unibraw, 1997). Sesampai dilaboratotium, kemudian preparat daun diamati dengan mikroskop monokuler untuk mengetahui struktur anatominya. Jaringan yang diamati adalah jaringan epidermis atas, jaringan bunga karang, jaringan palisade dan jaringan epidermis bawah termasuk indeks stomata. Analisis data yang dilakukan menggunakan analisis analisis statistik yaitu uji $\mathrm{T} 2$ sampel bebas dan kemudian dilanjutkan dengan analisis deskriptif. Hal yang sama dilakukan pada jenis tumbuhan yang sama di dua lokasi yang berbeda, baik di tempat yang terdampak polusi udara maupun di lokasi yang tidak terdampak.

\section{Material, bahan dan alat}

Sampel tumbuhan yang dikoleksi kemudian dilanjutkan untuk diidentifikasi nama ilmiahnya dengan menggunakan literatur yang ada di herbarium atau dengan membandingkan dengan spesimen yang ada di Herbarium Universitas Andalas (ANDA).

Bahan-bahan yang dipakai untuk mengawetkan sampel untuk diidentifikasi yaitu spritus dan FAA dengan komposisi Formalin : Asam Asetat Glasial : Alkohol ( $5: 5: 90$ ). Sedangkan alat-alat yang digunakan dapat yaitu alat-alat untuk koleksi seperti gunting tanaman, parang, botol awetan basah vol.50 ml, plastik klip dan kantong plastik (vol $2 \mathrm{~kg}, 5 \mathrm{~kg}, 10$ 
$\mathrm{kg}$ dan $50 \mathrm{~kg}$ ); alat-alat untuk mencatat dan mengukur yaitu alat tulis, meteran kayu lipat, GPS Garmin GIS Map 60; alat-alat untuk "prosessing specimen" yaitu koran, tali raffia, dan perangkat pengeringan, oven dan alat untuk dokumentasi yakni kamera digital Sony Cybershoot 8,1 mega pixel dengan $5 \mathrm{x}$ optical zoom (Taufiq dan Alponsin, 2018).

\section{Cara kerja}

Data didapatkan dengan cara koleksi langsung dilapangan. Pengkoleksian mengikuti Smith (1985). Sebelum di koleksi akan dilakukan pengambilan foto dan pencatatan karakter-karakter yang nantinya tidak terbawa seperti warna, aroma, ukuran. Disamping pengoleksian sampel untuk keperluan identifikasi nama ilmiah, pada individu yang sama juga dilakukan pengoleksian sampel untuk pengamatan karakter jaringan daun.

Di Herbarium akan dilakukan pembuatan spesimen dari koleksi yang didapatkan di lapangan dan pengamatan karakter lebih detail. Pembuatan spesimen mengkuti Jain and Rao (1977). Pengamatan karakter lebih detail akan menggunakan binokuler sampai perbesaran $40 \mathrm{X}$. Acuan terminologi akan mengikuti Harris and Harris (1954), Smith (1981), Stearn (1992) dan Hickey and King (2000).

\section{Analisa Data}

Data dianalisa secara deskriptif. Identifikasi mengacu pada literatur yang relevan, seperti Holltum (1950), Smith (1985) dan Theilade (1999).

\section{Preparat Epidermis Daun}

Daun yang telah dikoleksi di bersihkan bagian adaksial dan abaksialnya dengan tissue. Kemudian oleskan kutex pada permukaan sampel dan biarkan sampai mengering. Tempelkan selotip pada permukaan yang telah diberi kutex. Kemudian cabut selotip sehingga kutex yang menempel pada permukaan sampel terbawa, kemudian tempelkan selotip pada kaca objek dan amati sampel di bawah mikroskop di Laboratorium Struktur dan Perkembangan Tumbuhan, Jurusan Biologi FMIPA Universitas Andalas.

Pada cetakan epidermis ini, parameter yang diamati adalah distribusi stomata atau tipe daun (hipostomatik, epistomatik dan amfiostomatik), panjang dan lebar stomata serta kerapatan stomata (Jumlah stomata/luas bidang pandang) dan indeks stomata (jumlah stomata/(jumlah stomata+epidermis) $\mathrm{x}$ 100). Pengukuran panjang dan lebar stomata diamati dari cetakan epidermis daun sesuai dengan metoda Kubínová (1994) dan Albrechtová et al. (2007) dengan analysis image ImageJ v 1.49 seperti pada Gambar 1.

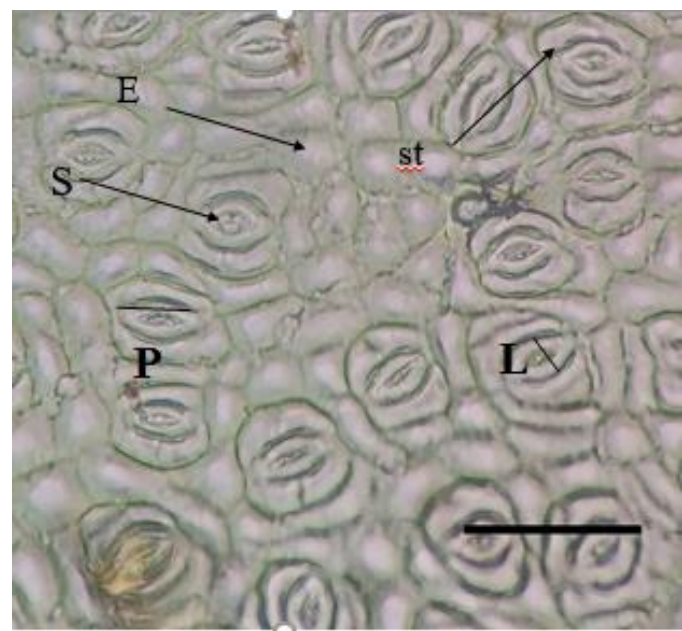

Gambar 1. Cara mengukur panjang dan lebar stomata pada preparat epidermis; (S: Stomata; E: Epidermis; st: Sel tetangga; $\mathrm{P}$ : Panjang stomata; L: Lebar)

Kandungan Klorofil Daun 
Sebanyak $0,5 \quad \mathrm{~g}$ daun muda dihomogenisasi dengan $80 \%$ aseton sebanyak $50 \mathrm{ml}$ dengan cara digerus di dalam mortar selama 5 menit atau sampai sampel daun halus. Selanjutnya, ekstrak di sentrifus selama 15 menit dengan kecepatan 3500 rpm untuk memisahkan natan dan supernatan. Kemudian dilakukan analisis pigmen fotosintetik (klorofil a, b dan klorofil total) menggunakan metode spektrofotometri. Optical Density (OD) dari ekstrak diukur pada panjang gelombang 663 dan $645 \mathrm{~nm}$.

Kandungan klorofil (mg/g) dapat dihitung dengan rumus:

Klorofil $\mathrm{a}=[12,7($ OD 663) $-2,69$

(OD 645)] x V/(1000) (w)

Klorofil $b=[22,9(\mathrm{OD} 645)-4,68$

(OD 663)] x V/(1000) (w)

Klorofil total $=[20,2(\mathrm{OD} 645)+8,02$ (OD 663)] x V/(1000) (w)

Keterangan :

OD : Optical density dari spektrofotometer

$\mathrm{V}$ : Volume aseton yang dipakai

$\mathrm{W}$ : berat segar sampel daun yang dipakai

(Arnon, 1994)

\section{HASIL DAN PEMBAHASAN}

Pengambilan sampel telah dilakukan di ke dua kawasan baik itu yang terdampak oleh debu semen ataupun yang tidak terdampak. Untuk kawasan terdampak dilakukan pengambilan sampel di sekitar perumnas indarung Kelurahan Limau Manis Selatan, Kecamatan Lubuk Kilangan. Sedangkan untuk yang tidak terkena dampak polusi semen dilakukan sampling di sekitar kampus Unand dan di Pasar Baru, Kecamatan Pauh, Kota Padang. Masing-masing kawasan / site tersebut dilakukan pengoleksian sampel terhadap tumbuhan dengan 3 tipe habit (bentuk tumbuh) yang berbeda yaitu pohon, semak dan terna. Sejumlah 8 (delapan) jenis (4 jenis pohon, 2 jenis semak, dan 2 jenis terna) tumbuhan telah dikoleksi di dua tipe kawasan yang berbeda (terdampak dan tidak terdampak polusi debu semen). Masing-masing kawasan diambil 2 individu untuk tiap jenisnya, sehingga sebanyak 32 individu telah dikoleksi di lapangan dan kemudian dibawa ke Laboratorium Struktur dan Perkembangan Tumbuhan Jurusan Biologi FMIPA Univeristas Andalas untuk diamati karakter anatominya setelah itu juga dibawa ke Laboratorium Fisiologi Tumbuhan Jurusan Biologi FMIPA Universitas Andalas untuk pemeriksaan kandungan klorofil.

\section{Indeks Stomata}

Data hasil pengamatan stomata terhadap keseluruhan sampel individu pertama baik pada kawasan 1 (terkena dampak) ataupun kawasan 2 (kontrol) dapat dilihat pada Tabel 1. dan Gambar 3.

Tabel 1. Komparasi nilai indeks stomata (\%) daun tumbuhan di kawasan terkena dampak polusi debu semen dan yang tidak terkena dampak (individu pertama).

\begin{tabular}{rlcc}
\hline No & Jenis & kontrol & terdampak \\
\hline 1 & $\begin{array}{l}\text { Mangifera } \\
\text { indica }\end{array}$ & 32,3 & 10 \\
\hline 2 & $\begin{array}{l}\text { Persea } \\
\text { americana }\end{array}$ & 30,7 & 12,3 \\
\hline 3 & Rhoe discolor & 19 & 8 \\
\hline 4 & Ixora javanica & 27 & 10 \\
\hline 5 & $\begin{array}{l}\text { Acacia } \\
\text { auriculiformis }\end{array}$ & 25,7 & 21,1 \\
\hline 6 & Aglaonema sp. & 15 & 9,5 \\
\hline 7 & Polyalthia & 20,8 & 19 \\
\hline
\end{tabular}




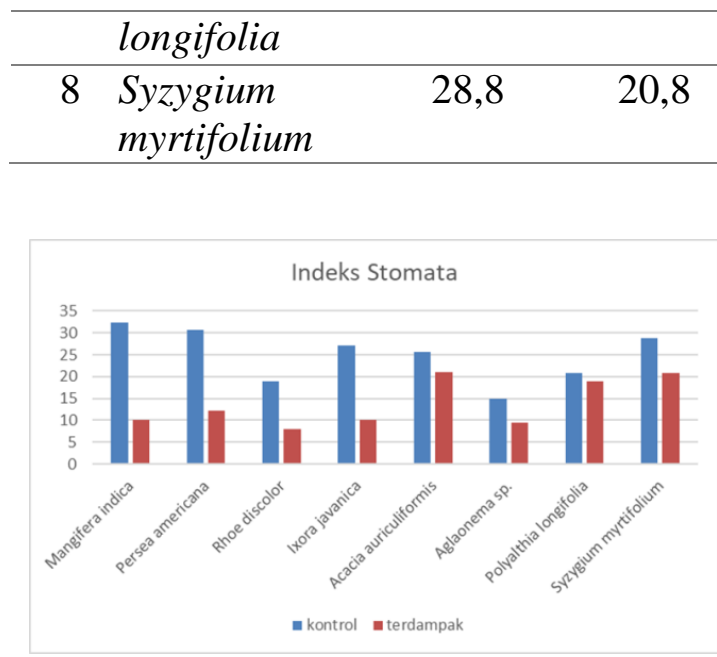

Gambar 3. Komparasi nilai indeks stomata daun tumbuhan di kawasan terkena dampak polusi debu semen dan yang tidak terkena dampak (individu pertama).

Dari Tabel 1. dan Gambar 3. dapat diperhatikan bahwa nilai indeks stomata daun tumbuhan individu pertama ini jelas nampak bahwa jenis yang terdampak menunjukkan tren penurunan pada semua jenis yang diamati. Jenis yang memiliki perbedaan nilai indeks stomata paling tinggi antara pada kelompok kontrol dengan terdampak adalah Mangifera indica (32,2\% : $10 \%)$. Sedangkan yang paling sedikit jarak bedanya adalah jenis Polyalthia longifolia (20,8\% : 19\%). Dengan demikian dapat diartikan bahwa Mangifera indica memiliki sensitifitas lebih tinggi dibandingkan dengan tujuh jenis tumbuhan lainnya dan Polyalthia longifolia adalah jenis yang memiliki sensitifitas paling rendah.

Mutaqin, et.al. (2016) melaporkan bahwa adanya perbedaan persentase kerusakan stomata pada daun mangga (Mangifera indica) yang berada di pinggir Jalan Kidang Pananjung dengan di Cagar Alam Pananjung. Pada stomata di pinggir jalan memiliki persentase kerusakan stomata lebih besar, yaitu sebesar 39,61\% dibandingkan dengan kerusakan stomata pada daun mangga di cagar alam sebesar 16,1 \%. Hal ini mengindikasikan bahwa pencemaran udara berpengaruh terhadap tumbuhan, khususnya dalam proses membuka dan menutupnya stomata.

\begin{tabular}{|c|c|c|c|c|c|}
\hline \multicolumn{6}{|c|}{ Group Statistics } \\
\hline & Tipe Kawasan & $\mathrm{N}$ & Mean & Std. Deviation & $\begin{array}{c}\text { Std. Error } \\
\text { Mean }\end{array}$ \\
\hline \multirow[t]{2}{*}{ Indeks Stomata } & Kontrol & 8 & 24,9125 & 6,07440 & 2,14763 \\
\hline & Terdampak & 8 & 13,8375 & 5,51075 & 1.94835 \\
\hline
\end{tabular}

\begin{tabular}{|c|c|c|c|c|c|c|c|c|c|c|}
\hline \multicolumn{11}{|c|}{ Independent Samples Test } \\
\hline & & \multicolumn{2}{|c|}{$\begin{array}{l}\text { Levene's Test for Equality of } \\
\text { Variances }\end{array}$} & \multicolumn{7}{|c|}{ t-test for Equality of Means } \\
\hline & & \multirow[b]{2}{*}{$\mathrm{F}$} & \multirow[b]{2}{*}{ Sig. } & \multirow[b]{2}{*}{$t$} & \multirow[b]{2}{*}{ df } & \multirow[b]{2}{*}{ Sig. (2-tailed) } & \multirow{2}{*}{$\begin{array}{c}\text { Mean } \\
\text { Difference }\end{array}$} & \multirow{2}{*}{$\begin{array}{l}\text { Std. Error } \\
\text { Difference }\end{array}$} & \multicolumn{2}{|c|}{$\begin{array}{l}95 \% \text { Confidence Interval of the } \\
\text { Difference }\end{array}$} \\
\hline & & & & & & & & & Lower & Upper \\
\hline Indeks Stomata & $\begin{array}{l}\text { Equal variances } \\
\text { assumed }\end{array}$ &, 013 &, 912 & 3,819 & 14 &, 002 & 11,07500 & 2,89972 & 4,85573 & 17,29427 \\
\hline & $\begin{array}{l}\text { Equal variances not } \\
\text { assumed }\end{array}$ & & & 3,819 & 13,869 & ,002 & 11,07500 & 2,89972 & 4,85023 & 17,29977 \\
\hline
\end{tabular}

Gambar 4. Tabel output hasil Uji T 2-sampel bebas antara nilai indeks stomata daun tumbuhan di kawasan terkena dampak polusi debu semen dan yang tidak terkena dampak (individu pertama).

Guna mendapatkan presisi perbedaan nilai yang jelas maka selanjutnya dilakukan analisis statistik uji $\mathrm{T}$ 2-sampel bebas. Deskirpsi statistik pada Gambar 4. memperlihatkan bahwa nilai rata-rata indeks stomata pada site terdampak lebih kurang hanya sebagian dari nilai indeks stomata pada kawasan kontrol $(12,84 \%: 24,91 \%)$. Kemudian perbedaan nilai ini dikonfirmasi oleh tabel Independent Sampel Test bahwa nilai indeks stomata daun tumbuhan antara dua site tersebut memiliki nilai beda yang 
signifikan. Hal ini ditunjukkan oleh nilai sig. (2-tailed) sebesar 0,002 <0,005. Perbedaan yang nyata ini sejalan dengan pembuktian bahwa polusi debu semen mempunyai pengaruh yang nyata terhadap berkurangnya nilai indeks stomata tumbuhan.

Tabel 2. Komparasi nilai indeks stomata (\%) daun tumbuhan di kawasan terkena dampak polusi debu semen dan yang tidak terkena dampak (individu kedua).

\begin{tabular}{rlcc}
\hline \multicolumn{1}{l}{$\begin{array}{l}\text { N } \\
\mathbf{0}\end{array}$} & Jenis & $\begin{array}{l}\text { kontro } \\
\text { l }\end{array}$ & $\begin{array}{l}\text { terdampa } \\
\mathbf{k}\end{array}$ \\
\hline $\mathbf{1}$ & $\begin{array}{l}\text { Mangifera } \\
\text { indica }\end{array}$ & 30 & 19,6 \\
\hline $\mathbf{2}$ & $\begin{array}{l}\text { Persea } \\
\text { americana }\end{array}$ & 37,5 & 23 \\
\hline $\mathbf{3}$ & $\begin{array}{l}\text { Rhoe discolor } \\
\mathbf{4}\end{array}$ & 16 & 10 \\
\hline $\mathbf{5}$ & $\begin{array}{l}\text { Axora javanica } \\
\text { auriculiformis }\end{array}$ & 25 & 16 \\
\hline $\mathbf{6}$ & Aglaonema $\mathrm{sp}$. & 13 & 18,4 \\
\hline $\mathbf{7}$ & $\begin{array}{l}\text { Polyalthia } \\
\text { longifolia }\end{array}$ & 20 & 20 \\
\hline $\mathbf{8}$ & $\begin{array}{l}\text { Syzygium } \\
\text { myrtifolium }\end{array}$ & 23,4 & 19,7 \\
\hline
\end{tabular}

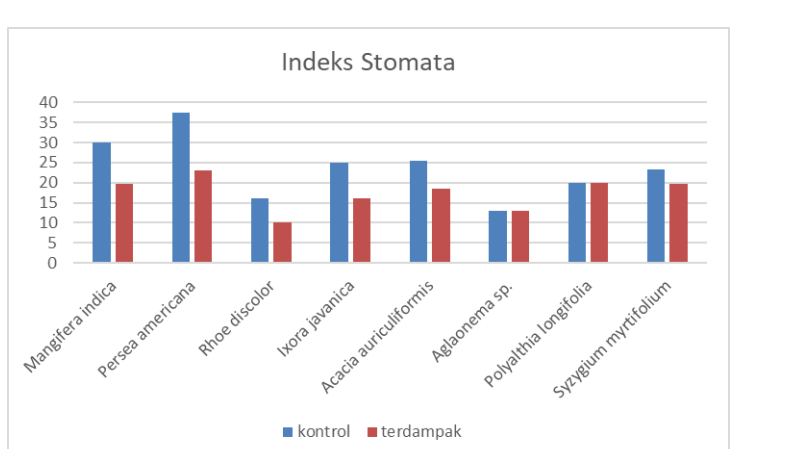

Gambar 5. Komparasi nilai indeks stomata daun tumbuhan di kawasan terkena dampak polusi debu semen dan yang tidak terkena dampak (individu kedua).

Sama dengan yang disajikan pada tumbuhan individu pertama Dari Tabel 2. dan Gambar 5. dapat diperhatikan bahwa nilai indeks stomata daun tumbuhan individu kedua ini juga memperlihatkan bahwa jenis yang terdampak cenderung menunjukkan tren penurunan pada hampir semua jenis yang diamati. Terdapat beberapa jenis yang tidak mempunyai selisih nilai indeks dengan kata lain belum mendapatkan pengaruh yang nyata dari polusi yang ada. Adapun jenis tumbuhan tersebut adalah Aglaonema sp. dan Polyalthia longifolia yang mana masing-masing memiliki selisih nilai sebesar 0 (nol). Untuk jenis yang memiliki perbedaan nilai indeks paling tinggi antara lokasi kontrol dengan lokasi yang terdampak ditempati oleh Persea americana (37,5\%: $23 \%)$.

Dengan demikian dapat kita simpulkan bahwa dari ke delapan jenis tanaman yang diamati tersebut terdapat dua jenis yang memiliki sensitifitas yang tinggi terhadap pencemaran udara yaitu Mangga (Mangifera indica) dan Pokat (Persea americana). Kedua-duanya memiliki habit berupa pohon, dimana secara stratifikasi mempunyai peluang paling besar untuk menerima dampak dari pencemaran udara tersebut dibandingkan dengan semak dan vegetasi dasar. Disamping itu tipe tajuk juga berpengaruh terhadap tangkapan polutan di udara. Merujuk kepada Widyanti (2012), Tanaman Mangifera indica dan Persea Americana memiliki tipe tajuk yang sama yaitu Rounded yang melebar kearah horizontal, sedangkan tanaman jenis Polyalthia longifolia memiliki tipe tajuk Columnar yang hanya memanjang dari atas kebawah dengan lebar tajuk tajuk yang relatif kecil. Tipe tajuk yang rounded tersebut memungkinkan tumbuhan tersebut menerima partikulat lebih banyak dibandingkan dengan tipe tajuk yang columnar.

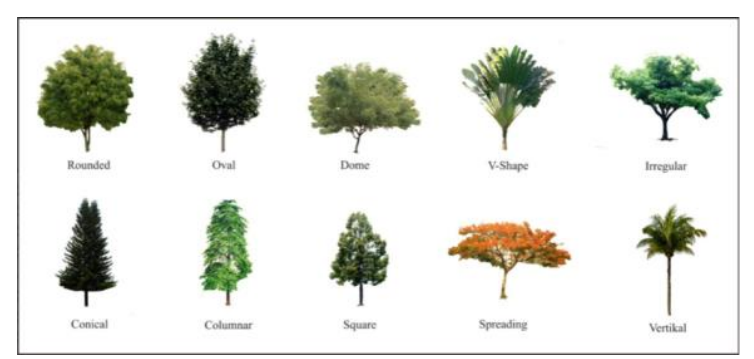

Gambar 6. Bentuk Tajuk Pohon. Sumber: Widyanti (2012)

Berdasarkan pengamatan, tumbuhan vegetasi dasar Rheo discolor hanya memiliki 
nilai indeks stomata $10-16 \%$ dan Aglaonema sp. juga konsisten di angka 13\%, sedangkan kelompok pohon memiliki angka yang jauh lebih tinggi yaitu hingga mencapai angka $37,5 \%$. Artinya pohon sebagai struktur tumbuhan yang cenderung memiliki peluang paling tinggi dalam memperoleh cahaya matahari juga memiliki indeks stomata yang lebih tinggi dibandingkan dengan jenis vegetasi dasar yang cenderung ternaungi oleh jenis dari semak dan pohon dari terpaan cahaya matahari. Hal ini sesuai dengan yang disampaikan oleh Fahn (1991) yang mengemukakan bahwa jumlah stomata akan berkurang seiring dengan menurunnya intensitas cahaya.

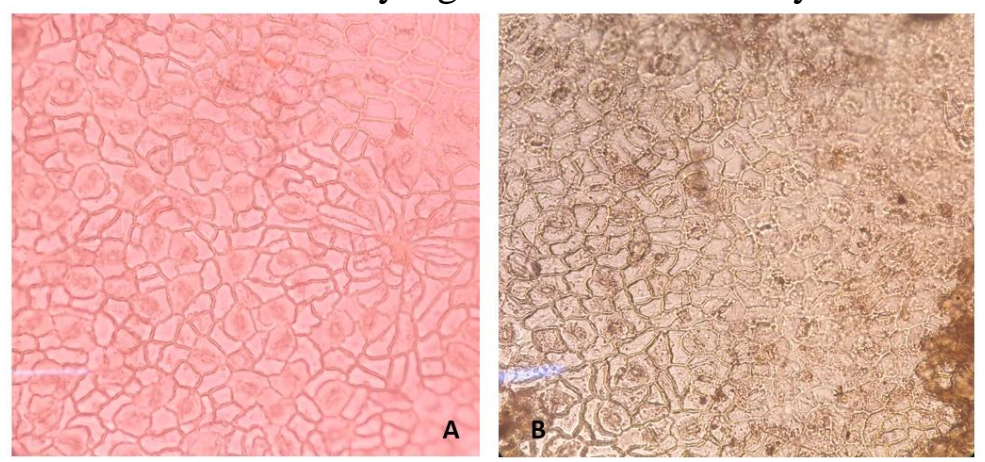

Gambar 7. Foto sayatan paradermal tanaman Pokat (Persea americana) pada dua lokasi berbeda. A: tidak terpapar polutan; B: Terpapar polutan.

\begin{tabular}{|c|c|c|c|c|c|}
\hline \multicolumn{6}{|c|}{ Group Statistics } \\
\hline & Tipe Kawasan & $\mathrm{N}$ & Mean & Std. Deviation & $\begin{array}{l}\text { Std. Error } \\
\text { Mean }\end{array}$ \\
\hline \multirow[t]{2}{*}{ Indeks Stomata } & Kontrol & 8 & 23,7875 & 7,76631 & 2,74580 \\
\hline & Terdampak & 8 & 17,4625 & 4,23082 & 1,49582 \\
\hline
\end{tabular}

Independent Samples Test

\begin{tabular}{|c|c|c|c|c|c|c|c|c|c|c|}
\hline & & \multicolumn{2}{|c|}{$\begin{array}{l}\text { Levene's Test for Equality of } \\
\text { Variances }\end{array}$} & \multicolumn{7}{|c|}{ t-test for Equality of Means } \\
\hline & & \multirow[b]{2}{*}{$\mathrm{F}$} & \multirow[b]{2}{*}{ Sig. } & \multirow[b]{2}{*}{$\mathrm{t}$} & \multirow[b]{2}{*}{ df } & \multirow[b]{2}{*}{ Sig. (2-tailed) } & \multirow{2}{*}{$\begin{array}{c}\text { Mean } \\
\text { Difference }\end{array}$} & \multirow{2}{*}{$\begin{array}{l}\text { Std. Error } \\
\text { Difference }\end{array}$} & \multicolumn{2}{|c|}{$\begin{array}{l}\text { 95\% Confidence Interval of the } \\
\text { Difference }\end{array}$} \\
\hline & & & & & & & & & Lower & Upper \\
\hline Indeks Stomata & $\begin{array}{l}\text { Equal variances } \\
\text { assumed }\end{array}$ & \multirow[t]{2}{*}{1,541} & \multirow[t]{2}{*}{,235 } & \multirow[t]{2}{*}{2,023} & 14 & .063 & 6,32500 & 3,12681 &,- 38133 & 13,03133 \\
\hline & $\begin{array}{l}\text { Equal variances not } \\
\text { assumed }\end{array}$ & & & & 10,818 & ,069 & 6,32500 & 3,12681 &,- 57117 & 13,22117 \\
\hline
\end{tabular}

Gambar 8. Gambar tabel output hasil Uji T 2-sampel bebas antara nilai indeks stomata daun tumbuhan di kawasan terkena dampak polusi debu semen dan yang tidak terkena dampak (individu kedua).

Sama halnya dengan individu yang pertama, maka selanjutnya dilakukan analisis statistik uji $\mathrm{T}$ 2-sampel bebas. Untuk individu yang kedua ini, nilai indeks stomata daun tumbuhan antara dua site yang berbeda tersebut tidak tergolong signifikan perbedaannya setelah dikonfirmasi melalui analisis Independent Sampel Test. Hal ini ditunjukkan oleh nilai sig. (2-tailed) sebesar $0,063>0,005$. Walaupun demikian, terdapat perbedaan nilai rata-rata indeks stomata antara ke dua site tersebut. Deskirpsi statistik pada Gambar 8. memperlihatkan bahwa perbedaan nilai rata-rata indeks stomata pada site terdampak dengan nilai indeks stomata pada kawasan kontrol adalah $17,46 \%: 23,78 \%$. Hal ini tetap menguatkan konsistensi terhadap kecenderungan penurunan nilai indeks stomata sejalan dengan adanya polusi udara.

\section{Kandungan Krolofil}

Kandungan krolofil juga sudah diperiksa terhadap nomor sampel yang sama antara dua site yang berbeda. Didapatkan hasil bahwa kandungan krorofil pada kawasan yang terdampak memiliki kecendrungan lebih rendah dari pada jenis pada kawasan yang tidak terdampak (kontrol). Data mengenai ini dapat dilihat pada Tabel 3. dan 
disajikan dalam bentuk visual pada Gambar 9 .

Tabel 3. Komparasi nilai kandungan klorofil tumbuhan di kawasan terkena dampak

polusi debu semen dan yang tidak terkena dampak (gabungan kedua individu).

\begin{tabular}{ccccccc}
\hline No & $\begin{array}{c}\text { No } \\
\text { Habit }\end{array}$ & Habit & $\begin{array}{c}\text { No } \\
\text { Jenis }\end{array}$ & Spesies & Asap & Bersih \\
\hline $\mathbf{1}$ & 1 & Pohon & 1 & Mangifera sp. & 1,9125 & 2,1075 \\
\hline $\mathbf{2}$ & 1 & Pohon & 1 & Mangifera sp. & 1,8876 & 2,1075 \\
\hline $\mathbf{3}$ & 1 & Pohon & 2 & Persea sp. & 1,7747 & 1,923 \\
\hline $\mathbf{4}$ & 1 & Pohon & 2 & Persea sp. & 1,6979 & 1,923 \\
\hline $\mathbf{5}$ & 3 & Terna & 3 & Rhoe discolor & 1,0959 & 1,396 \\
\hline $\mathbf{6}$ & 3 & Terna & 3 & Rhoe discolor & 0,8526 & 1,396 \\
\hline $\mathbf{7}$ & 2 & Semak & 4 & Ixora sp. & 1,4529 & 1,726 \\
\hline $\mathbf{8}$ & 2 & Semak & 4 & Ixora sp. & 1,398 & 1,726 \\
\hline $\mathbf{9}$ & 1 & Pohon & 5 & Acacia sp. & 1,5635 & 2,006 \\
\hline $\mathbf{1 0}$ & 1 & Pohon & 5 & Acacia sp. & 1,5909 & 2,006 \\
\hline $\mathbf{1 1}$ & 3 & Terna & 6 & Aglaonema sp. & 0,8365 & 1,045 \\
\hline $\mathbf{1 2}$ & 3 & Terna & 6 & Aglaonema sp. & 0,7888 & 1,045 \\
\hline $\mathbf{1 3}$ & 1 & Pohon & 7 & Polyalthia sp. & 2,261 & 2,809 \\
\hline $\mathbf{1 4}$ & 1 & Pohon & 7 & Polyalthia sp. & 1,7947 & 2,809 \\
\hline $\mathbf{1 5}$ & 2 & Semak & 8 & $\begin{array}{c}\text { Syzygium } \\
\text { oleana }\end{array}$ & 1,6207 & 1,978 \\
& & Semak & 8 & $\begin{array}{c}\text { Syzygium } \\
\text { oleana }\end{array}$ & 1,7104 & 1,978 \\
\hline $\mathbf{1 6}$ & 2 & S & &
\end{tabular}

Kandungan Klorofil

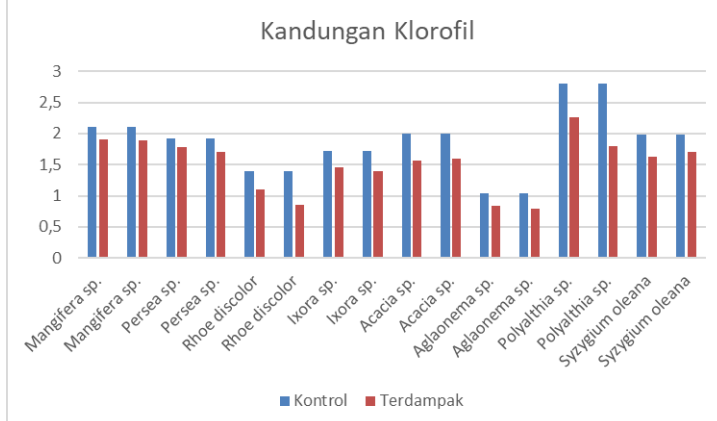

Gambar 9. Komparasi nilai kandungan klorofil tumbuhan di kawasan terkena dampak polusi debu semen dan yang tidak terkena dampak (gabungan kedua individu).

Deskirpsi statistik pada Gambar 11. memperlihatkan bahwa nilai rata-rata kandungan klorofil pada site terdampak lebih rendah dari kandungan stomata pada kawasan kontrol $(1,51 \mu \mathrm{g} / \mathrm{mL}: 1,96 \mu \mathrm{g} /$ $\mathrm{mL})$. Kemudian perbedaan nilai ini dikonfirmasi oleh tabel Independent Sampel Test bahwa nilai kandungan klorofil tumbuhan antara dua site tersebut memiliki nilai beda yang signifikan. Hal ini ditunjukkan oleh nilai sig. (2-tailed) sebesar $0,014<0,005$. Perbedaan yang nyata ini sejalan dengan pembuktian bahwa polusi debu semen mempunyai pengaruh yang nyata terhadap berkurangnya kandungan klorofil tumbuhan. Hal ini mengindikasikan bahwa pencemaran udara berpengaruh terhadap tumbuhan, khususnya dalam proses membuka dan menutupnya stomata (Gambar 10). Pada saat stomata membuka, dimana kondisi udara lembab, maka gas-gas yang ada di udara yang terserap tumbuhan akan menyebabkan menutupnya stomata, akibat akumulasi polutan pada sel penutup, sel penjaga, serta jaringan mesofil dan mempengaruhi kinerja ion-ion dalam proses fotosintesis (Romadhoni dan Ubudiyah, 2011). Hal senada dinyatakan oleh Solihin (2014) bahwa pemaparan emisi kendaraan bermotor terhadap tumbuhan dapat meningkatkan tingginya persentase menutupnya celah stomata di samping rendahnya kadar klorofil dan adanya kerusakan morfologi daun. Menurut hasil penelitian Sukarsono (1998) kerusakan abnormalitas anatomi daun seluruh tumbuhan yang diteliti dengan kandungan 
pencemar di udara secara umum menunjukkan adanya pengaruh yang nyata terutama gas $\mathrm{SO} 2$ dan $\mathrm{Pb}$ terhadap abnormalitas masing-masing jaringan. Kerusakan anatomi daun (termasuk juga kerusakan klorofil dan kloroplast) akibat pencemaran udara disebabkan karena pengaruh gas pencemar tersebut yang mempengaruhi $\mathrm{pH}$ medium sel dan jaringan yang menjadi lebih rendah (ion-ion $\mathrm{H}+$ meningkat). Pada penelitiannya, Romadhoni dan Ubudiyah (2011) juga menambahkan bahwa semakin lama paparan polutan pada lapisan epidermis dan stomata daun akan semakin meningkat juga kerusakan, indeks kerusakan, jumlah dan indeks kerusakan stomata serta klorofil daun Pterocarpus indicus. Kemudian Welburn (1999) mengatakan pollutan $\mathrm{SO} 2$ dan $\mathrm{NO} 2$ yang rendah merangsang pertumbuhan tanaman tetapi bila kedua polutan tersebut berinteraksi pada tanaman akan menyebabkan kerusakan tanaman.

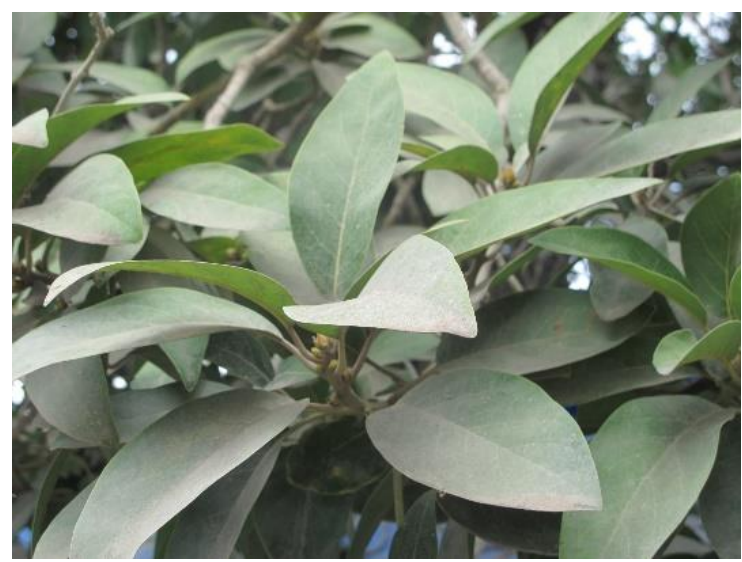

Gambar 10. Salah satu tanaman yang terpapar partikulat debu di sekitar kegiatan pabrik Semen. Jenis Persea americana (pokat). Foto diambil oleh Ahmad Taufiq.

Group Statistics

\begin{tabular}{|ll|r|r|r|r|}
\hline & Tipe Kawasan & N & Mean & Std. Deviation & $\begin{array}{c}\text { Std. Error } \\
\text { Mean }\end{array}$ \\
\hline Kadar Klorofil & Kontrol & 16 & 1,9660 &, 54437 &, 13609 \\
& Terdampak & 16 & 1,5149 &, 42502 &, 10626 \\
\hline
\end{tabular}

Independent Samples Tes

\begin{tabular}{|c|c|c|c|c|c|c|c|c|c|c|}
\hline \multicolumn{11}{|c|}{ Independent Samples Test } \\
\hline & & \multicolumn{2}{|c|}{$\begin{array}{l}\text { Levene's Test for Equality of } \\
\text { Variances }\end{array}$} & \multicolumn{7}{|c|}{ t-test for Equality of Means } \\
\hline & & $\mathrm{F}$ & Sig. & $\mathrm{t}$ & df & Sig. (2-tailed) & $\begin{array}{c}\text { Mean } \\
\text { Difference }\end{array}$ & $\begin{array}{l}\text { Std. Error } \\
\text { Difference }\end{array}$ & Lower & Upper \\
\hline & $\begin{array}{l}\text { Equal variances not } \\
\text { assumed }\end{array}$ & & & 2,613 & 28,333 & .014 & .45109 & .17266 & .09760 & .80458 \\
\hline
\end{tabular}

Gambar 11. Gambar tabel output hasil T 2-sampel bebas antara nilai kandungan klorofil tumbuhan di kawasan terkena dampak polusi debu semen dan yang tidak terkena dampak (gabungan kedua individu).

Descriptive Statistics

Dependent Variable: Chlorophyll Content
\begin{tabular}{|ll|r|r|r|}
\hline Life forms & Sites & \multicolumn{1}{c|}{ Mean } & Std. Deviation & \multicolumn{1}{c|}{ N } \\
\hline Trees & Affected Site & 1,8104 &, 22128 & 8 \\
& Control Site & 2,0122 &, 08265 & 6 \\
& Total & 1,8968 &, 19933 & 14 \\
\hline Shrubs & Affected Site & 1,5455 &, 14512 & 4 \\
& Control Site & 1,8520 &, 14549 & 4 \\
& Total & 1,6988 &, 21199 & 8 \\
\hline Herbs & Affected Site &, 8935 &, 13766 & 4 \\
& Control Site & 1,2205 &, 20265 & 4 \\
& Total & 1,0570 &, 23724 & 8 \\
\hline Total & Affected Site & 1,5149 &, 42502 & 16 \\
& Control Site & 1,7402 &, 37159 & 14 \\
& Total & 1,6201 &, 41037 & 30 \\
\hline
\end{tabular}

Tests of Between-Subjects Effects

Dependent Variable: Chlorophyll Content
\begin{tabular}{|l|r|r|r|r|r|}
\hline Source & $\begin{array}{c}\text { Type III Sum } \\
\text { of Squares }\end{array}$ & \multicolumn{1}{c|}{ df } & Mean Square & \multicolumn{1}{c|}{ F } & \multicolumn{1}{c|}{ Sig. } \\
\hline Corrected Model & $4,200^{\text {a }}$ & 5 &, 840 & 29,490 &, 000 \\
Intercept & 67,450 & 1 & 67,450 & 2367,952 &, 000 \\
Life_forms & 3,749 & 2 & 1,874 & 65,799 &, 000 \\
Sites &, 540 & 1 &, 540 & 18,967 &, 000 \\
Life_forms * Sites &, 025 & 2 &, 012 &, 436 &, 652 \\
Error &, 684 & 24 &, 028 & & \\
Total & 83,621 & 30 & & & \\
Corrected Total & 4,884 & 29 & & & \\
\hline
\end{tabular}

a. $\mathrm{R}$ Squared $=, 860$ (Adjusted R Squared $=, 831$ )

Gambar 12. Tabel output hasil Uji ANOVA dua arah antara nilai kandungan klorofil tumbuhan di kawasan terkena dampak polusi debu semen dan yang tidak terkena dampak (gabungan kedua individu). 
Pada Gambar 12. juga dapat kita perhatikan bahwa terdapat perbedaan jumlah klorofil pada masing-masing tipe habitus yang berbeda. Terna memiliki perbedaan terbesar antara lokasi $(0,33 \mu \mathrm{g} / \mathrm{mL})$, diikuti oleh semak $(0,31 \mu \mathrm{g} / \mathrm{mL})$ dan kemudian pohon $(0,2 \mu \mathrm{g} / \mathrm{mL})$. Sedangkan Uji ANOVA dua arah menunjukkan bahwa baik dalam hal bentuk tumbuh/habit (life form) maupun lokasi (sites) yang terdampak dan tidak terdampak, secara signifikan memengaruhi kandungan klorofil ( $p$-value $=0,00)$.

\section{KESIMPULAN}

Pada penelitian ini didapatkan kesimpulan bahwa pada katakter stomata, analisis Independent T-test mengungkapkan bahwa terdapat nilai beda nyata antara tanaman yang terpapar dengan yang tidak terpapar partikulat debu. Variasi stomata dari tiap habit tumbuhan memperlihatkan bahwa kelompok pohon memiliki perbedaan terbesar antara lokasi (146 / mm2), diikuti oleh semak (44,6 / mm2) dan kemudian terna $(14,9$ / mm2). Selanjutnya juga telah dilakukan Uji ANOVA dua arah yang menunjukkan bahwa baik dalam hal bentuk tumbuh maupun lokasi, tidak berpengaruh signifikan kerapatan stomata ( $\mathrm{p}$-value = $0,071 ; 0,208)$.

Demikian juga halnya pada kandungan klorofil. Analisis independent T-test mengungkapkan adanya perbedaan yang signifikan $(p$-value $=0,037)$ terhadap kelompok yang tercemar. Ketika ditelusuri pada tiap tipe habitus tumbuhan tersebut, terna memiliki perbedaan terbesar antara lokasi $(0,33 \mu \mathrm{g} / \mathrm{mL})$, diikuti oleh semak $(0,31 \mu \mathrm{g} / \mathrm{mL})$ dan kemudian pohon $(0,2 \mu \mathrm{g}$ / mL). Sedangkan Uji ANOVA dua arah menunjukkan bahwa baik dalam hal bentuk tumbuh maupun lokasi, secara signifikan memengaruhi kandungan klorofil ( $\mathrm{p}$-value = 0,00). Artinya, pada ketiga bentuk tumbuh tumbuhan yang diamati, baik kepadatan stomata atau kandungan klorofilnya berkurang karena adanya polusi udara akibat aktifitas Pabrik Semen tersebut.

\section{DAFTAR PUSTAKA}

Fahn, A. 1991. Anatomi Tumbuhan. Gajah Mada University Press. Yogyakarta.

Fardiaz, S. (1992). Polusi Air dan Udara. Kanisius. Yogyakarta.

Fitter, A.H. dan Hay, R.K. (1994). Environmental Physiology of Plant. Gadjah Mada Uni- versity Press. Yogyakarta.

Gibbs, R.D. 1950. Botany, An Evalutionary Approach. Toronto: The Blakiston Company.

Harris, J.G., \& Harris, M.W. 1954. Plant Identification Terminology. USA: Spring Lake Publishing

Hickey, M., \& Clive K. 2000. The Cambridge Illustrated Glossary of Botanical Terms. Cambridge University Press.

[IPCC] Intergovernmental Panel on Climate Change. 2001. Climate Change, The scientific basis. Cambridge University Press. Cambridge. UK.

Irwan, B. 2006. Analisi Vegetas Untuk Pengelolaan Kawasan Hutan Lindung Pulau Marsegu, Kabupaten Seram Bagian Barat, Provinsi Maluku. Tesis Sekolah Pascasarjana. Universitas Gadjah Mada. Yogyakarta.

Jebb, M.; Cheek, M. (1997). "A skeletal revision of Nepenthes (Nepenthaceae)". Blumea. 42: 1-106.

Kinnaird, M.F. 1997. Sulawesi Utara, Sebuah Panduan Sejarah Alam. Jakarta: Yayasan Pengembangan Wallacea.

Lloyd, F.E. 1942. The Carnivoruos Plant. New York: The Rolland Press Company.

Leach, C.G. 1940. Insect Transmition of Plant Disease. New York: Mc Grow Hill Book Company. 
Locatelli, B., M. Kannien, M. Brockhaus, C. J. P. Colfer, D. Murdiyarso dan $\mathrm{H}$. Santoso. 2009. Menghadapi Masa Depan Yang Tak Pasti "Bagaimana Hutan Dan Manusia Beradaptasi Terhadap Perubahan Iklim". CIFORD. Bogor Indonesia.

Mansur, M. 2006. Nepenthes Kantong Semar yang Unik. Jakarta: Penebar Swadaya.

Metthews, E. G. and R.C. Kitching. 1994. Insect Ecology. Queensland: University of Queensland Press.

Mukono. 2006. Prinsip dasar Kesehatan Lingkungan Edisi Kedua. Surabaya: Binacipta

Mulyanto, E., Dewi, C., dan Ahmad D.S. 2000. Kantung Semar (Nepenthes sp.) di Lereng Gunung Merbabu. Biodiversitas 1 (2): 54-58.

Mutaqin A Z, Ruly B, Tia S, Mohamad N, Radewi S F. 2016. Studi Anatomi Stomata Daun Mangga (Mangifera Indica) Berdasarkan Perbedaan Lingkungan. Jurnal Biodjati 1 (1): 1318.

Radford, A. E. 1986. Fundamental of Plant Systematic. Harper and Row Publishers Inc. New York.

Romadhoni, M. dan I. W. A. Ubudiyah. 2011. Pengaruh Polusi Udara terhadap Stomata Daun Angsana (Pterocarpus indicus).

http://muhammadromadhoni.blogspot.co .id/2011/11/pengaruh-polusi-udaraterhadap-stomata.html. Diakses pada 19 Maret 2021.

Salami, Miftahul. 2018. "Pencemaran Udara Akibat Asap PT Semen Padang." Padang: Jurusan Teknik Lingkungan Fakultas Teknik Universitas Andalas.

Smith, R.M. 1985. A review of Bornean Zingiberaceae: 1 (Alpinieae). Notes from the Royal Botanical Garden Edinburgh 42: 295-314.

Solihin, A. 2014. Morfologi Daun, Kadar Klorofil, dan Stomata Glodokan (Polyalthia longifolia) pada Daerah dengan Tingkat Paparan Emisi Kendaraan yang Berbeda di Yogyakarta. Skripsi. Program Studi Biologi Fakultas Sains dan Teknologi Universitas Islam Negeri Sunan Kalijaga. Yogyakarta

Stearn, W.T. 1992. Botanical Latin. History, Grammar Syntax, Terminology and Vocabulary. Fourth Edition. David \& Charles. Brunel House, Newton Abbot, Devon.

Taufiq A and Chairul M. 2012. "Profil Keanekaragaman Hayati PT. Semen Padang." Padang: PT. Semen Padang.

Taufiq A dan Alponsin. 2018. "Kajian Potensi Kualitas Kayu Melalui Uji Marka Anatomi Pada Tanaman Puspa (Schima Wallichii (DC.) Korth. Sebagai Tanaman Revegetasi Lahan Pascatambang." Biogenesis: Jurnal Ilmiah Biologi 6 (1): 1-10. https://doi.org/10.24252/bio.v6i1. 3946.

Theilade, I.,\& Mood, J. 1999. Six new species of Zingiber (Zingiberaceae) from Borneo. Nordic Journal of Botany, 19 (5). Pp. 513-524.

Treshow, M. dan Anderson, F. A. (1989). Plant Stress from Air Pollution. John Willey \& Sons, Ltd. Chishester, New York.

UNIBRAW. (1997). Pedoman Biologi Dasar Praktikum Malang. Jurusan Biologi, U- NIBRAW. Malang.

Widyanti R. 2012. Evaluasi Fungsi Dan Struktur Pohon Pada Lanskap Jalan Kapten Muslihat -- Terminal Laladon, Bogor. Skripsi Sarjana Pertanian pada Fakultas Pertanian Institut Pertanian Bogor. 